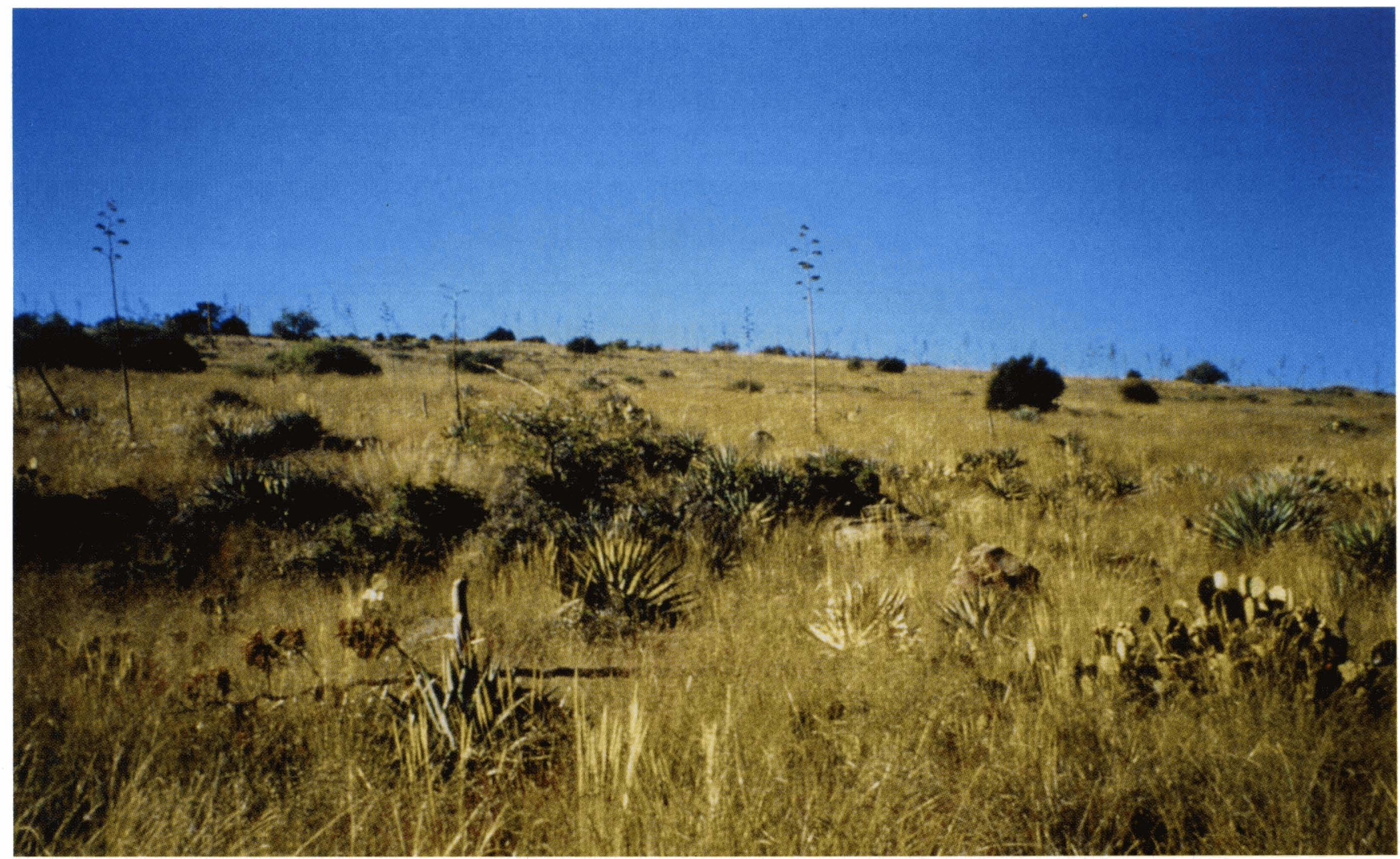

\title{
Dutchwoman Butte: A Relict Grassland in Central Arizona
}

\section{Norman Ambos, George Robertson and Jason Douglas}

Relict areas, which have had a minimum of impacts from man's activities, are scarce. Dutchwoman Butte, in central Arizona, supports a relict grassland community that, due to an isolated location and steep topography, has not been grazed by domestic livestock. It represents a valuable opportunity to examine a grassland in pristine condition and establish baseline conditions for vegetation, soil, and watershed. These data can be used for comparisons with similar grazed areas.

During the fall of 1993, 1994, and 1997 a Forest Service team of soil scientists, hydrologists, and range conservationists visited the site to collect a variety of data pertaining to terrestrial ecosystems.

\section{Location and Physical Description}

Dutchwoman Butte is located seven miles north of Roosevelt, Arizona within the Tonto Basin Ranger District of the Tonto National Forest. It is a one hun- dred acre, isolated butte, lying in the Central Highlands (Transition Zone) between the Basin and Range province and

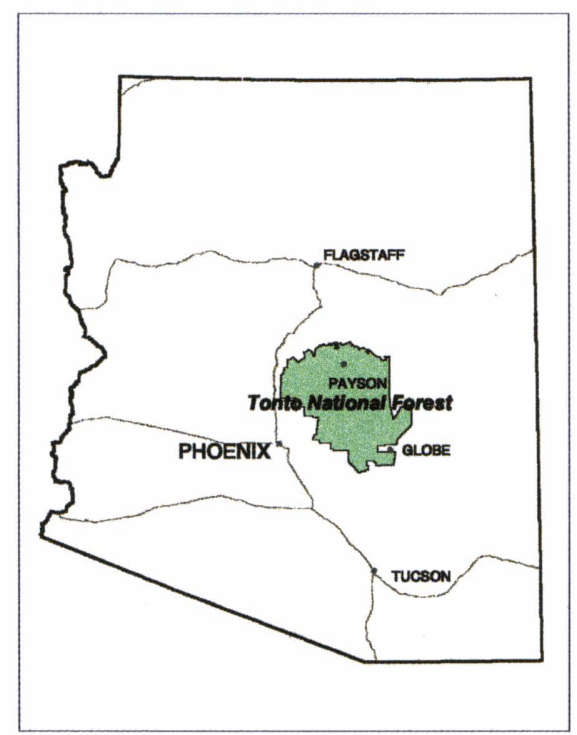

Fig. 1. Location of the Tonto National Forest within Arizona. the Colorado Plateau. The geology is the Pre-Cambrian Apache Group consisting of limestone, shale, conglomerate, and

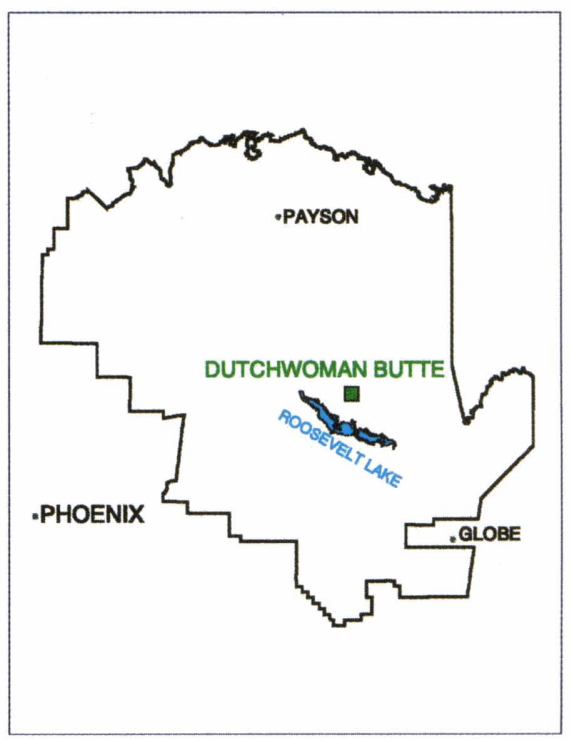

Fig. 2. Location of Dutchwoman Butte within the Tonto National Forest. 
quartzite. Quartzite is the dominant rock on Dutchwoman Butte. The elevation ranges from approximately 4,720 to 5000 feet. The summit of the butte is not level but is tilted to the southeast with a slope of about $20 \%$ and lies 500 to 1,000 feet above the surrounding lowlands.

\section{Climate}

No climatic data were available from within the site. Data from surrounding weather stations were used to extrapolate climatic conditions. The climate of the area is semi-arid with two distinct rainy seasons. The summer monsoon season is characterized by intense thunderstorms, and the winter rainy season is associated with Pacific frontal storms producing gentle rains and occasional snows. About $60 \%$ of the precipitation falls during the winter period. Summers are hot with normal high temperatures above $90^{\circ} \mathrm{F}$. Winter temperatures frequently drop below freezing at night. The mean annual precipitation on Dutchwoman Butte is estimated to be 17 inches.

The total precipitation during the 1993 and 1994 study period was above normal with near normal summer precipitation. The period preceding the 1997 data collection, however, was marked by a long-term period of below normal precipitation. Data from three nearby weather stations show that for the 30 month period preceding October 1997 the precipitation was 25 to $40 \%$ below normal. This variability is not unusual for the area and would be considered normal for long-term records.

\section{Vegetation Community}

The vegetation community on Dutchwoman Butte consists of a semidesert grassland with widely scattered redberry juniper. It lies high above the Sonoran desert shrubland of Tonto Basin but below the woodlands of the higher plateaus to the north. Common shrubs include catclaw acacia, agave, banana yucca, and Engelmann pricklypear. Common half shrubs include false mesquite and buckwheat. The most common grasses are sideoats grama, hairy grama, and plains lovegrass.

The vegetation indicates a transition between the semi-arid grasslands of lower elevations and the woodlands
The following vegetation and ground cover data were collected on Dutchwoman Butte from random transects. The data were collected from two areas. The data from Site 1 were collected on areas of deeper soils, the most common of the area. The second data (Site 2) were obtained from the shallower, rockier soils. The deeper soils tended to produce more grass while the rockier soils tended to favor buckwheat at the expense of grass. Plant names are from the 1982 National List of Scientific Plant Names.

\begin{tabular}{|c|c|c|c|}
\hline \multirow[t]{2}{*}{ Trees/Shrubs/Half-Shrubs } & & \multicolumn{2}{|c|}{ \% Canopy Cover } \\
\hline & & Site 1 & Site2 \\
\hline White-ball Acacia & Acacia angustissima & 0.1 & --- \\
\hline Catclaw Acacia & Acacia gregii & 1.0 & --- \\
\hline Agave & Agave parryi & 1.2 & 0.2 \\
\hline False Mesquite & Calliandra eriophylla & 10.8 & 6.1 \\
\hline Hedgehog Cactus & Echinocereus sp. & 0.2 & 2.0 \\
\hline Wright Buckwheat & Erigonum wrightii & 4.7 & 16.9 \\
\hline Redberry Juniper & Juniperus erythrocarpa & 2.0 & --- \\
\hline Englemann Prickleypear & Opuntia phaecantha & 1.7 & 0.1 \\
\hline Banana Yucca & Yucca bacata & 3.1 & --- \\
\hline Total Trees/Shrubs/Half- Shrubs & & 24.8 & 25.3 \\
\hline \multicolumn{4}{|l|}{ Forbs } \\
\hline Aster & Aster sp. & $\mathrm{T}$ & $\mathrm{T}$ \\
\hline Sunflower & Helianthus sp. & $\mathrm{T}$ & $\mathrm{T}$ \\
\hline Deer-vetch & Lotus rigidus & --- & 1.0 \\
\hline \multicolumn{4}{|c|}{ Grasses } \\
\hline Total Forbs & & $\mathrm{T}$ & 1.0 \\
\hline Threeawn & Aristida sp. & 1.2 & 2.1 \\
\hline Cane Beardgrass & Bothriochloa barbinodis & 0.3 & 3.4 \\
\hline Sideoats Grama & Bouteloua curtipendula & 13.9 & 9.7 \\
\hline Hairy Grama & Bouteloua hirsuta & 8.6 & 8.0 \\
\hline Plains Lovegrass & Eragrostis intermedia & 5.9 & 5.4 \\
\hline Tanglehead & Heteropogon contortus & --- & 0.1 \\
\hline Curly Mesquite & Hilaria belangeri & 1.8 & --- \\
\hline Prairie Junegrass & Koeleria pyramidata & 3.9 & 1.4 \\
\hline Green Sprangletop & Leptochloa dubia & 0.8 & 1.3 \\
\hline Bull Muhly & Muhlenbergia emersleyi & --- & 2.5 \\
\hline Bottlebrush Squirreltail & Sitanion hystrix & 2.7 & 0.2 \\
\hline Sand Dropseed & Sporobolus cryptandrus & 0.2 & --- \\
\hline \multirow[t]{2}{*}{ Ground Cover Componentss } & & \multicolumn{2}{|c|}{ \% Canopy Cover } \\
\hline & & Site 1 & Site2 \\
\hline Total Grasses & & 39.3 & 34.1 \\
\hline Grass Basal Area & & 7.9 & 6.7 \\
\hline Tree/Shrub/Half-Shrub Basal Area & & 1.8 & 1.9 \\
\hline Litter $>1.2 \mathrm{~cm}$ & & 20.7 & 27.3 \\
\hline Rock Fragments $>0.2 \mathrm{~cm}$ & & 32.8 & 40.6 \\
\hline Bare Soil & & 36.1 & 22.3 \\
\hline Cryptogams & & 0.0 & 0.0 \\
\hline
\end{tabular}

$\mathrm{T}=$ Trace. The species was encountered during the transect but the canopy cover was less than $0.1 \%$. 
The following plants were observed on the butte but were not encountered on any transect line:

\begin{tabular}{|ll|}
\hline Desert Spoon & Dasylirion wheeleri \\
\hline Snakeweed & Gutierrezia sarothrae \\
\hline Beargrass & Nolina microcarpa \\
\hline Pancake Pear & Opuntia chlorotica \\
\hline Honey Mesquite & Prosopis velutina \\
\hline Turbinella Oak & Quercus turbinella \\
\hline Coffeeberry & Rhamnus crocea ilicifolia \\
\hline Sage & Artemisia sp. \\
\hline Bugbush & Sida procumbens \\
\hline Arizona Cottontop & Digitaria californica \\
\hline Red Sprangletop & Leptochloa filiformis \\
\hline Wolftail & Lycurus phleoides \\
\hline Plains Bristlegrass & Setaria macrostachya \\
\hline Slim Tridens & Tridens muticus \\
\hline
\end{tabular}

This is by no means a complete list since other species may have been present but were not observed. above. Woodland zone indicators, such as redberry juniper and turbinella oak, are present but the vegetation is more similar to that of the semi-arid grasslands. The vegetation composition suggests that the area has a climate at the extreme cool/moist end of the semi-arid grassland gradient.

\section{Soils}

There are two dominant soils types on Dutchwoman Butte. The most common (Aridic Argiustolls, fine, smectitic, thermic, deep, very gravelly loams) occupies about $70 \%$ of the area. It consists of a deep, well drained soil with a dark brown, organic rich, cobbly loam surface over a dark reddish brown clay subsoil. The second most common soil (Aridic Argiustolls, loamy-skeletal, mixed, superactive, thermic, moderately deep, very stony loams) occupies about $20 \%$ of the area, normally near the margins of the butte. It consists of a moderately deep, well drained soil with a reddish brown, organic rich, very stony loam surface over a dark reddish brown very cobbly loam subsoil. Smaller areas of very shallow soil also occur in random patterns.

All of the soils have large amounts of litter and plant cover and abundant organic matter within the soil. These features promote stable granular surface soil aggregates and contribute to a low bulk density leading to stable soils. These soils have good infiltration rates and provide a good medium for root growth. There are very few indicators of overland flow such as rills, sediment or litter deposits, or pedestalled rocks and plants. All visual signs indicate that a very high proportion of the precipitation that falls on Dutchwoman Butte enters the soil.

\section{Vegetation and Forage Production}

The most striking aspect of Dutchwoman Butte is the diversity, density, and vigor of the grasses. A total of twelve grass species occurs in greater than trace canopy cover densities. The canopy coverage of grasses ranges from approximately $35 \%$ to $40 \%$ and the vigor is high with most of the grama
Two soil descriptions were taken on Dutchwoman Butte. The first was taken at approximately mid slope. The second was taken near the top of the slope on an extremely rocky surface. The descriptions follow: (Colors are for dry soil unless otherwise noted.)

Pedon1: Aridic Argiustoll, fine, smectitic, thermic.

This soil occurs at an elevation of 4800 feet near mid slope on a linear surface with a gradient of $20 \%$ and an aspect of 110 degrees. The soil formed in colluvial and residual material derived from the Apache Group (limestone, shale, quartzite, conglomerate). The residual material is quartzite.

The "A" horizon, with a depth of 0 to 3 inches, is a dark brown cobbly loam containing $4.7 \%$ organic carbon. It has moderate fine to coarse granular structure and contains many very fine and fine roots and many very fine and fine tubular pores. The soil reaction is moderately acid.

The "AB" horizon, with a depth of 3 to 7 inches, is dark brown very cobbly clay loam containing $2.0 \%$ organic carbon. It has moderate, medium subangular blocky structure parting to strong medium granular structure and contains many very fine and fine roots with common very fine and fine tubular pores. The soil reaction is neutral.

The "Bt" horizons, with a depth of 7 to 28 inches, are a reddish brown to dark reddish brown cobbly or stony clay containing about $1.2 \%$ to $1.6 \%$ organic carbon. They have strong angular blocky structure in the upper part and weak prismatic structure in the lower part. They contain common very fine and fine roots in the upper part and few very fine roots in the lower part. There are few fine pores throughout. Pressure faces are found on peds. The reaction ranges from neutral in the upper part to slightly alkaline in the lower part.

The "Bk" horizon ranges form 28 to 41 inches. It is a reddish brown very cobbly clay. It is massive and contains no roots and few pores. It contains soft masses and disseminated lime and is slightly alkaline.

Pedon 2: Aridic Argiustoll, loamy-skeletal, mixed, superactive, thermic.

This soil occurs at an elevation of 5000 feet near the upper part of the slope. The surface is linear to convex with a gradient of $25 \%$ and an aspect of 130 degrees. The soil formed in colluvial and residual material derived from the Apache Group (limestone, shale, quartzite, conglomerate). The residual material is quartzite.

The "A" horizon, with a depth of 0 to 3 inches, is a reddish brown very stony loam. It has moderate fine granular structure and contains many fine and medium roots, and many fine and medium, tubular pores. The soil reaction is neutral.

The "AB" horizon, with a depth of 3 to 7 inches, is a dark reddish brown very cobbly loam. It has moderate medium subangular blocky structure parting to moderate fine and medium granular structure and contains common to many very fine to coarse roots. There are many very fine to fine tubular pores and the soil reaction is neutral.

The "Bt" horizons, with a depth of 7 to 33 inches, are dark reddish brown to reddish brown cobbly, very cobbly, or very stony clay loams. They have moderate to strong medium and coarse structure. They contain common very fine to medium roots in the upper part grading to few very fine to medium roots in the lower part. They have many very fine and fine tubular pores in the upper part of the horizon and common very fine and fine tubular pores in the lower part. The soil reaction is slightly acid in the upper part grading to moderately acid in the lower part. Fractured quartzite bedrock is encountered at a depth of 84 inches. 
During the past several years the Southwestern Region of the USDA Forest Service has been developing a protocol for assessing soil quality. The procedure that was developed examines three primary soil functions: hydrologic (the ability of the soil to accept, hold, and release water); stability (the ability of the soil to resist erosion); and nutrient cycling. Soils are placed into one of three condition classes (satisfactory, impaired, or unsatisfactory) based on their ability to meet the soil function criteria. Soil condition classes are used to assess forest management and recommend measures to enhance soil quality through changes in management or by implementing restoration.

The hydrologic function is evaluated by the following indicators: surface structure, surface pore space, rupture resistance, near surface subzones, bulk density, infiltration, and penetration resistance. Stability is determined by using the following: soil loss models (Universal Soil Loss Equation \{USLE\}, Revised Universal Soil Loss Equation $\{$ RUSLE\}), visible erosion, pedestalling, erosion pavement, soil deposition, and loss of surface horizons. Nutrient cycling is evaluated by these indicators: the vegetative community composition, surface litter, coarse woody material, and root distribution. Several indicators may influences more than one function. Surface litter, for instance, will influence soil stability and hydrologic function as well as nutrient cycling. The overall weight of all criteria is used to determine the soil condition rating.

The soils on Dutchwoman Butte were evaluated during the process of developing soil quality standards. Along with soils from other areas, the Dutchwoman Butte soils served as a baseline to demonstrate soils that were functioning properly and exhibited satisfactory soil quality.

grasses reaching knee high and some of the species such as cane beardgrass and green sprangletop reaching waist high. The dominant species are sideoats grama, hairy grama, and plains lovegrass. These three grasses account for about $70 \%$ of the grass canopy. Curly mesquite accounts for only about $5 \%$ of the total grass component (1.8\% canopy coverage) on the deep, fine textured soils. This is commonly the dominant species on many heavily grazed ranges. In such places it may account for more than $90 \%$ of the grass canopy. Another feature of the grass community is the extreme patchiness of the species com- position. Many of the species seemed to occur in localized swards despite no apparent differences in soil characteristics. This was especially true of the less common species. For example green sprangletop and cane beardgrass, which only occupied canopies of 0.8 and $0.3 \%$ respectively, often could be found in swards covering localized areas in nearly pure stands.

Another feature of the vegetation is the scarcity of snakeweed. It was not found during the vegetation transects. Only a few plants were observed on the butte while on the grazed rangeland below the butte, snakeweed was quite common.

Grass basal area was not high, measured at seven or eight percent, but this is probably typical of a bunchgrass community. Most of the ground cover came from grass litter totaling approximately 20 to $25 \%$. This illustrates the importance of leaving ungrazed grass to build up litter since litter accounts for the bulk of vegetative ground cover and facilitates water infiltration. Total effective vegetative cover (plant basal area plus persistent litter $>1 / 2$ inch) was approximately 30 to $35 \%$. Cryptogamic crusts were scarce. Intense competition with vascular plants may limit the occurrence of these communities in grasslands.

Forage production data were collected in October 1994 and again in October 1997. Grasses, buckwheat, and false mesquite were clipped, air dried, and weighed to produce the following results: tation in the 30-month period preceding the 1997 data collection was below normal with the summer precipitation in the previous four months being well below normal.

As expected, the forage production was strongly influenced by precipitation. The 1994 data showed 1116 lbs/acre of forage during a period when precipitation was slightly above normal. The forage production in 1997 was only $463 \mathrm{lbs} / \mathrm{acre}$, or about $40 \%$ of the 1994 production. As noted in the climate section, the 1997 data were collected during a period of prolonged drought. The Palmer Drought Severity Index indicates that the period from late 1995 through 1997 was one of the most severe droughts since early in the 20th century. Even with the reduction in forage production because of drought, Dutchwoman Butte was producing about four times as much forage as similar areas with a long-term history of grazing.

\section{Comparisons}

One of the values of Dutchwoman Butte is its use as a reference area that can be used to assess the impacts that have occurred on managed sites with similar ecosystems.

\section{Soil Comparison to Other Sites}

While laboratory data from similar soils on the Tonto National Forest are not available, the organic carbon content

\begin{tabular}{|lc|}
\hline \multicolumn{1}{|c|}{ 1994 Data } & Forage Production \\
\hline Grasses & $990 \mathrm{lbs} / \mathrm{acre}$ \\
\hline Buckwheat/False Mesquite & $126 \mathrm{lbs} / \mathrm{acre}$ \\
\hline Total forage & $1116 \mathrm{lbs} / \mathrm{acre}$ \\
\hline \multicolumn{1}{|c|}{ 1997 Data } & $358 \mathrm{lbs} / \mathrm{acre}$ \\
\hline Grasses & Forage Production \\
\hline Buckwheat/False Mesquite & $105 \mathrm{lbs} / \mathrm{acre}$ \\
\hline Total forage & $463 \mathrm{lbs} / \mathrm{acre}$ \\
\hline
\end{tabular}

As noted in the section on climate, the total precipitation in period preceding the 1994 data collection was slightly above normal although the summer precipitation was near normal. The precipi- from samples taken from the most common soil on Dutchwoman Butte can be put in perspective by comparing it to similar soils in Arizona. The data were compared to fifteen Mollisols (soils with 
dark, organic rich surface horizons) having Ustic (semi arid) moisture regimes listed in Soil Survey Laboratory Data and Descriptions for Some Soils of Arizona. The following table reveals that the soils on Dutchwoman Butte contain organic carbon levels that are much higher than are typical of Arizona soils of a similar climate. Note that the organic carbon content of the top three inches is three times that of the typical Arizona soil. of the total grass community. This species, which withstands grazing pressure well, was probably only a minor component of native grasslands but now dominates thousands of acres of rangeland. It was also observed that the canopy coverage of herbaceous forage species, which includes grasses and palatable half-shrubs, totals about $55 \%$ on Dutchwoman Butte but only 23\% on the Cross F allotment. Palatable halfshrubs include Wright buckwheat and false mesquite.

\section{Organic Carbon Content}

\begin{tabular}{|lccc|}
\hline $\begin{array}{l}\text { Depth } \\
\text { (Inches) }\end{array}$ & Dutchwoman Soils & \multicolumn{2}{c|}{ Arizona Soils } \\
\hline $0-3$ & $4.7 \%$ & Range of Organic Carbon & Average \\
\hline $3-7$ & $2.0 \%$ & 0.7 to $3.0 \%$ & $1.5 \%$ \\
\hline $7-28$ & $1.2-1.6 \%$ & 0.6 to $2.2 \%$ & $1.2 \%$ \\
\hline & 0.6 to $1.7 \%$ & $0.9 \%$ \\
\hline
\end{tabular}

\section{Comparison to a Typical Grazed Area}

Changes to soils and vegetation brought about by domestic livestock grazing can be put into perspective by comparing a typical grazed area with Dutchwoman Butte. The Cross F Allotment, located 25 miles to the northwest of Dutchwoman Butte, is fairly typical of many grazed ranges on the Tonto National Forest in that the grasslands are heavily dominated by curly mesquite. Data, collected on the Cross F Allotment and a range exclosure established in 1934 within the allotment, were compared to that of Dutchwoman Butte that has similar climate and soils. Both areas have the same soil type and the vegetation, for both areas, represents the cool/moist end of semi-desert grasslands.

Data from a vegetation transect on the Cross F allotment depict a site dominated by curly mesquite with a canopy coverage of $15.8 \%$. Only one other grass, sideoats grama at $0.1 \%$, occurs in more than trace amounts. Contrast this with the grass community on Dutchwoman Butte where twelve species with greater than $0.1 \%$ canopy occur and the total canopy of grasses is around $40 \%$. On Dutchwoman Butte, curly mesquite has a canopy of only $1.8 \%$ or only about $5 \%$
The bulk density of $0.93 \mathrm{~g} / \mathrm{cc}$ on Dutchwoman Butte is similar to the reading of $0.98 \mathrm{~g} / \mathrm{cc}$ obtained from the Cross F range study plot which has had long-term rest. The grazed area, however, outside of the exclosure, had a bulk density of $1.22 \mathrm{~g} / \mathrm{cc}$ which indicates enough soil compaction to cause a major reduction in the rate of water infiltration. The increase in bulk density of $24 \%$ on the grazed area is considered significant since a $15 \%$ increase in bulk density decreases water infiltration rates by about $50 \%$.

The soil structure on Dutchwoman Butte and within the Cross $F$ range study plot are strikingly different from the grazed portion of the Cross F allotment. The surface horizons on Dutchwoman and the range study plot have granular soil peds conducive to water infiltration, gas exchange and root growth, while the surface on the grazed Cross $\mathrm{F}$ portion has a dense, platy structure which limits infiltration and root development. In some heavily compacted soils, roots penetrate the dense plates only with difficulty and may be observed growing parallel to the surface.

Root development was also much more pronounced on Dutchwoman Butte and the range study plot. There were many very fine and fine roots $(>30$ per $\left.\mathrm{in}^{2}\right)$ in the surface horizons of these areas compared to few $\left(<5\right.$ per in $\left.{ }^{2}\right)$ in the grazed area. It was evident that, in the grazed areas, root development was not sufficient to rebuild organic matter supplies within the soil. The ungrazed areas had an adequate supply of roots to build organic matter reserves.

The soil characteristics of the Cross F allotment are typical of those soils on the Tonto National Forest that have had long-term impacts from grazing. Dutchwoman Butte offers a valuable comparison area to demonstrate that soils impacted from domestic livestock

\begin{tabular}{|lc|}
\hline Site & Bulk Density (g/cc) \\
\hline Dutchwoman Butte (heavy loam) & 0.93 \\
\hline Cross F Range Study Plot (heavy loam) & 0.98 \\
\hline Cross F Grazed (heavy loam) & 1.22 \\
\hline
\end{tabular}

grazing are not functioning at an optimum level and can be improved.

\section{Conclusions}

Dutchwoman Butte is an extremely valuable site for research in that it represents one of the very few semi-arid grassland habitats that have not been impacted by domestic livestock grazing. It is very useful in helping to assess preEuropean settlement conditions, changes that have been brought about by livestock grazing, and as a guide in establishing desired conditions. Soil charac- 

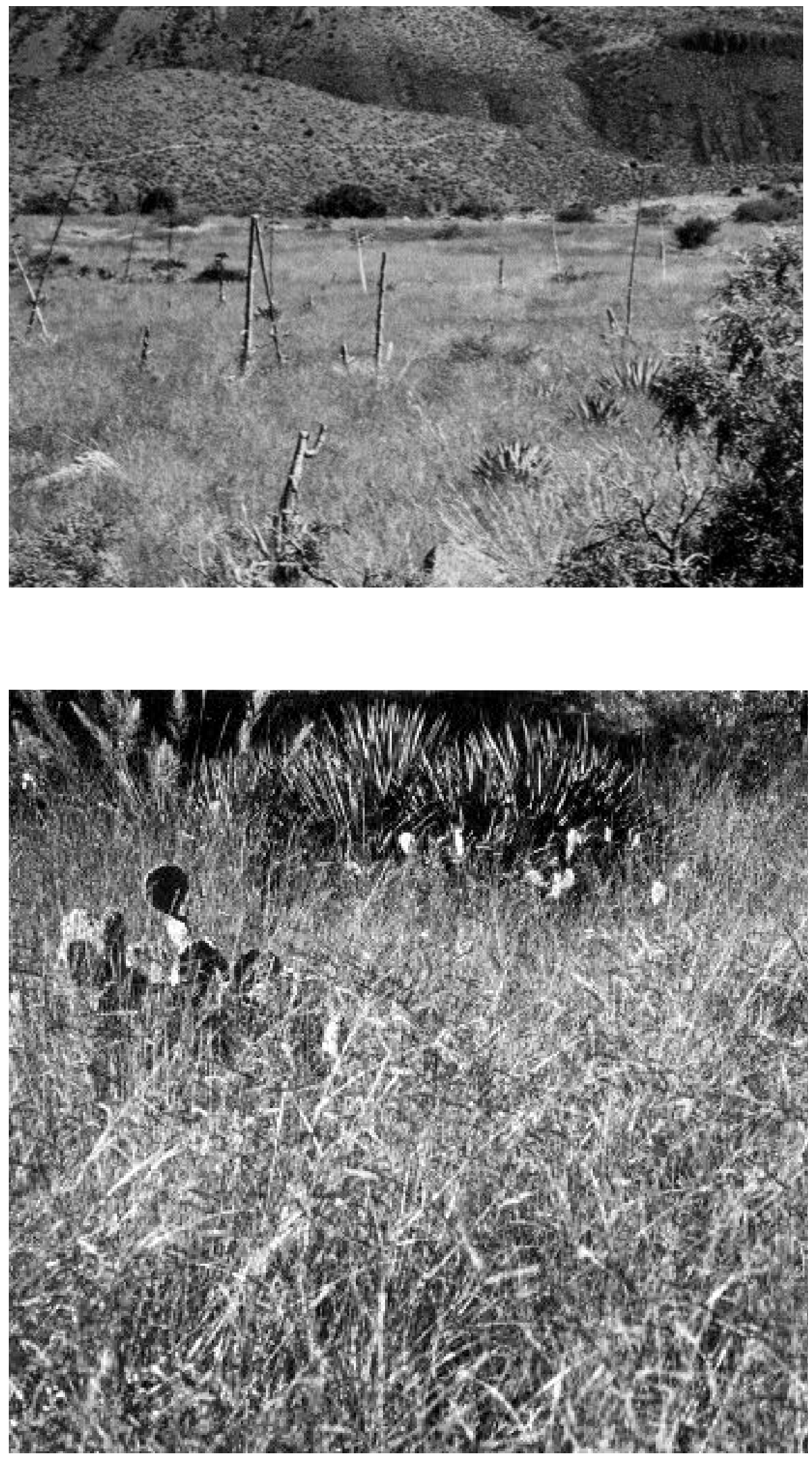

teristics of Dutchwoman Butte can be used as a baseline to evaluate soil conditions in other areas.

\section{References}

Daubenmire, R. 1959. A Canopy-Coverage Method of Vegetational Analysis. Northwest Science Vol.3, No. 1, 43-64.

National Climatic Data Center. 1994, 1995,1996, \& 1997. Climatological Data Annual Summary-Arizona 1994, 1995, 1996, \& 1997. Volumes 98, 99, 100, \& 101.

National Oceanic and Atmospheric Association. 1997. National Climate Data Center Web Site Graphic (drought_1690.gif) at www.ncdc.noaa.gov.

USDA 1993. Soil Survey Manual. 437 pp.

USDA 1996. Keys to Soil Taxonomy. 644 pp.

USDA Forest Service. 1999. Forest Service Handbook 2509.18 - Soil Management Handbook, Region Three Supplement 2509.18-99-1.

USDA Soil Conservation Service, SCSTP-159. 1982. National List of Scientific Plant Names, Volume 1. 416 pp.

USDA Soil Conservation Service, in cooperation with Arizona Agricultural Experiment Staion. 1974. Soil Survey Laboratory Data and Descriptions for Some Soils of Arizona. 383 pp.

Norman Ambos is the Forest Soil Scientist, Tonto National Forest, Phoenix, Arizona; George Robertson is a Supervisory Soil Scientist with the Arizona Terrestrial Ecosystems Survey Crew, Phoenix, Arizona; and Jason Douglas currently is a Fish and Wildlife Biologist with the U.S. Fish and Wildlife Service, Sacramento, California.

We thank the following who assisted in data collection and analysis: George Robertson, Rory Steinke, Grant Loomis, Linny Warren, Dennis Roy, Rhonda O'Byrne, Cindy Thornhill, Richard Fleishman, Jeff Hink, Rich Martin, Susan Gorman, and Jason Douglas. 